\title{
Security for all, development for some? The incorporation of security in UK development policy
}

\author{
Proof accepted by Journal of International Development, November 2014 \\ Dr. Eamonn McConnon \\ Postdoctoral Researcher \\ Institute for International Conflict Resolution and Reconstruction \\ Dublin City University \\ School of Law and Government \\ Glasnevin \\ Dublin 9 \\ Ireland
}

Email: eamonn.mcconnon@dcu.ie 


\begin{abstract}
This paper builds on existing research on the merging of development and security following 9/11. Whilst much of the current literature focuses on the development policy of the US, this paper examines the UK. Investigating arguments that the UK's coordination of security and development policy is concerned with security at home rather than in the developing world, the policy discourse of the UK's Department for International Development (DfID), Foreign and Commonwealth Office (FCO) and Ministry of Defence (MoD) is examined through its major policy documents for the period from the late 1990s to 2011. Two levels of analysis are used; a content analysis and a discourse analysis. In addition, this research draws on interviews with key informants within DfID. This paper argues that since 9/11 and the War on Terror, the UK has increasingly coordinated its foreign policy, development and security actors. As a result, DfID has given progressively greater attention to issues of national security in its policy discourse. This action is justified through a series of claims of common interest between actors across government and between the interests of developing countries and the UK. This merging of interests opens up space for development to be focused on ensuring UK national security. Whilst drawing on a paradigm of broader security, this instead reverses the principal of human security where national security is now a development problem.
\end{abstract}

Key Words: Security-development nexus, failed states, War on Terror, Human Security, radicalism, security, development 


\section{Introduction}

It has been argued that since 9/11 there has been a shift in development to meet security concerns. This is evident in attempts to coordinate development and security policies, leading to a closer relationship between development and military actors in the field. The concept of human security sought to merge security and development as a way of gaining greater attention for development issues. The principle aim of Human Security was to place the individual as the referent object of security and not the state (Henk, 2005; Newman, 2001: 239; UNDP, 1994). The concept is split between those who favour a narrow approach prioritising immediate threats to safety (Human Security Centre, 2005; Kaldor, 2007) and a broad approach that includes more systemic long term threats to security (UN, 2010; Institute for Democracy and Democracy and Electoral Assistance, 2006). While the broad approach focuses more on development solutions, the narrow approach advocates military intervention on the basis of the $\mathrm{R}_{2} \mathrm{P}^{1}$ doctrine. The fear among commentators (Bachman and Hönke, 2010; Ellis, 2004; Carmody, 2005; Ingram, 2007; Shannon, 2009) is that rather than security policy addressing development concerns, instead development concerns will be subverted by hard security considerations. The UK is an interesting case in this regard in that its Department for International Development (DfID) operates independently of the Foreign and Commonwealth Office. There is disagreement among commentators over whether DfID has maintained a poverty focus or whether it has shifted to addressing security concerns albeit in a more subtle way than USAID. Whilst some argue that DfID has maintained a firm stance on poverty alleviation over security concerns (Beall et al, 2006; Fitz-Gerald, 2006; Youngs, 2007; Wild and Elhawary, 2012), still others claim that UK development policy has become securitised and is geared towards protecting the West from the dangers caused by the underdevelopment of non-Western states (Abrahamsen, 2004, 2005; Duffield and Waddell, 2006; Carmody, 2011). Whilst some of the literature in this area addresses these issues in relation to isolated UK policy documents (Noxolo, 2012; Pugh et al., 2013; Ritchie, 2011), none of these arguments draw from a systematic, empirical analysis of UK development and security policy documents over an extended period of time.

\footnotetext{
${ }^{1}$ The Responsibility to Protect (R2P) is a doctrine which advocates military intervention in humanitarian crises where states have failed in their responsibility to protect their own citizens. See International Commission on Intervention and State Sovereignty International (2001) The Responsibility to Protect. Development Research Centre: Ottawa.
} 
This paper examines the evolution of DfID's discursive engagement with security issues over the period 1997-2012 and, through content and discourse analyses of major policy documents from DfID and other UK government agencies involved in development, together with relevant interview data ${ }^{2}$, argues that DfID has brought UK national security into the core of its policy discourse through a gradual process over this period by linking poverty and instability in the developing world to threats to UK national security such as terrorism and religious extremism. DfID has justified this shift through claims of common interest between development for people in the global South and security for the UK by drawing on the concept of human security wherein development is offered as a solution to national security problems. This is demonstrated through content and discourse analyses of major policy documents from DfID and other UK government agencies involved in development and an analysis of interviews with key officials within DfID. A content analysis ${ }^{3}$ is used to investigate the use of words associated with security over this extended period of time. This places the phenomenon within a broad time period and allows comparison with other development agendas over this time. However, there are limitations to word counting. A more nuanced understanding of how words are used and the meanings that are attached to them cannot be captured through a content analysis. In addition to this without a more detailed analysis of the text, there is a risk of over-interpreting high or low counts of words. To address these limitations the discourse analysis examines the manner in which these words are used and permits a deeper understanding of arguments they are used to construct. In addition, the issues raised by the content and discourse analyses are investigated in greater depth through interviews. Interviews were conducted with two former Secretaries of State for International Development, three DfID officials operating out of London, two DfID officials working in Kenya, one DfID official working in Ethiopia and one retired Major General from the British Military. Whilst a greater volume of interviewees is desirable, the methodological issue of gaining access is always a problem when relying on interviews. In particular,

\footnotetext{
${ }^{2}$ Interviews were conducted with nine respondents over the period of November 2012 to June 2013

${ }^{3}$ The content analysis was conducted using the word counting function on Adobe Reader XI. Headers, footers and bibliographies were excluded from the word count in order to avoid a possible skewing of the data. Variants of the words outlined in Table 2 were also included, for example for 'failed state' the terms 'state failure' and 'failing state' were also included in the count.
} 
it proved quite difficult to gain access to any MoD or FCO officials or members of the military. However, this sample of interviewees does give a mix of perspectives across levels of seniority, government departments and levels of operation between the field and London. The interviews add a further depth of analysis to the issues raised by the content and discourse analyses.

The first section of this paper is a discussion of the literature on the merging of security and development in UK policy. The second section gives an explanation of the documents chosen for this sample. The third section draws from a content analysis of these documents. The fourth section draws on both a discourse analysis of the sample documents and on interviews with key DfID officials.

\section{Security in DfID's Development Policy}

There is disagreement in the literature around DfID's engagement with security post9/11. On the one hand Fitz-Gerald (2006: 118), Waddell (2006: 543-546) and Youngs (2007: 11) argue that DfID has maintained a firm stance on poverty alleviation over security concerns. They point to clashes between DfID and the Ministry of Defence (MoD) over projects that prioritised foreign policy over poverty alleviation as evidence of this. Furthermore, others claim that DfID's leading principle is that the security of the world's poorest and most vulnerable is of utmost importance and should be prioritised over the security of Western donor countries (Beall et al 2006: 58). Still others claim that the closer relationship between security and development has led UK security policy to have a greater focus on development issues, stemming from a realisation of the limits of military power for ensuring global security (Pugh et al., 2013: 196; Ritchie, 2011: 370). However, as Howell and Lind (2009: 1288) point out, rather than a renewed poverty focus, a clear shift of development spending to meet WoT demands can be seen in the status of Iraq, Afghanistan and Pakistan as DfID's top recipients, whereas prior to 2001 they were not in the top 20 recipients. Similarly, studies on DfID's policy discourse argue that aid has become linked to UK national security (Noxolo (2012: 35) It is argued that developing countries are now seen as a source of insecurity to the West and that development aid is now used as a conflict resolution tool to shape the behaviour of African states so that they conform 
to liberal values of the free market economy and democracy (Abrahamsen, 2004; Duffield, 2005, 2006, 2010; Duffield and Waddell, 2006; Stern and Öjendal, 2010).

Of the existing studies on DfID, none analyses DfID's own policy discourse in a comprehensive manner, although the contributions of Abrahamsen (2004, 2005) analysing the public speeches of key state officials, Duffield and Waddell (2006) who draw on interviews with DfID officials and Stern and Öjendal (2010), Beall et al (2006) who examine excerpts of DfID’s 2005 security document, Noxolo (2012) Pugh et al (2013) and Ritchie's (2011) analyses of single documents released by the coalition government offer interesting insights into the subject. This paper complements this work through an analysis of key policy documents on development over the period 1997-2011, both from DfID and broader UK government, through content and discourse analyses and interviews with people working within DfID.

\section{UK Policy documents on security and development}

Table 1 Documents Sample in Chronological order

\begin{tabular}{|c|c|c|}
\hline Year & Publication Title & $\begin{array}{l}\text { Government } \\
\text { Department }\end{array}$ \\
\hline 1997 & $\begin{array}{l}\text { Eliminating World Poverty: A Challenge for the } 21^{\text {st }} \\
\text { Century }\end{array}$ & DfID White Paper \\
\hline 1999 & Poverty and the Security Sector & $\begin{array}{l}\text { DfID Security } \\
\text { Policy Paper }\end{array}$ \\
\hline 2000 & $\begin{array}{l}\text { Eliminating World Poverty: Making Globalisation Work } \\
\text { for the Poor }\end{array}$ & DfID White Paper \\
\hline 2003 & $\begin{array}{l}\text { The Global Conflict Prevention Pool: A Joint UK } \\
\text { Government Approach to Reducing Conflict }\end{array}$ & $\begin{array}{l}\text { DfID FCO and } \\
\text { MoD }\end{array}$ \\
\hline 2004 & $\begin{array}{l}\text { The Africa Conflict Prevention Pool: An Information } \\
\text { Document }\end{array}$ & $\begin{array}{l}\text { DfID, MoD and } \\
\text { FCO }\end{array}$ \\
\hline 2005 & $\begin{array}{l}\text { Fighting Poverty to Build a Safer World: A Strategy for } \\
\text { Security and Development }\end{array}$ & $\begin{array}{l}\text { DfID Strategy } \\
\text { Paper }\end{array}$ \\
\hline 2005 & Failed States Strategy & $\begin{array}{l}\text { DfID Strategy } \\
\text { Paper }\end{array}$ \\
\hline 2006 & $\begin{array}{l}\text { Eliminating World Poverty: Making Governance Work } \\
\text { for the Poor }\end{array}$ & DfID White Paper \\
\hline 2008 & $\begin{array}{l}\text { The National Security Strategy of the United Kingdom: } \\
\text { Security in an Interdependent World }\end{array}$ & UK Cabinet Office \\
\hline 2009 & $\begin{array}{l}\text { Eliminating World Poverty: Building Our Common } \\
\text { Future }\end{array}$ & DfID White Paper \\
\hline 2010 & Securing Britain in an Age of Uncertainty & UK Government \\
\hline
\end{tabular}




\begin{tabular}{|l|l|l|}
\hline 2011 & UK aid: Changing Lives, Delivering Results & $\begin{array}{l}\text { DfID Policy } \\
\text { Statement }\end{array}$ \\
\hline 2011 & Building Stability Overseas Strategy & $\begin{array}{l}\text { DfID FCO and } \\
\text { MoD }\end{array}$ \\
\hline 2011 & $\begin{array}{l}\text { Multilateral Aid Review Ensuring maximum value for } \\
\text { money for UK aid through multilateral organisations }\end{array}$ & $\begin{array}{l}\text { DfID Policy } \\
\text { Statement }\end{array}$ \\
\hline
\end{tabular}

Table 1, above, shows the sample of documents chosen for this analysis. Due to the coordination between DfID and other government departments outlined above this sample includes policy documents not just from DfID, but also collaborative documents with the FCO and the MOD and also broader UK Government documents dealing with national security. In this way both DfID's policy and broader UK government policy on security and development are examined. This paper contains an analysis of all DfID's White Papers from 1997 to present, (1997, 2000, 2006, 2009), key DfID strategy papers on issues of conflict, its bilateral and multilateral aid reviews from 2011 and all its Security documents from 1999 and 2005. White papers are important documents for analysing a government's policy at a particular time. They are used to highlight what the government sees as key challenges and their vision of how these challenges can be overcome. DfID is extremely prolific in communicating its policy through publications; White Papers are useful for analysis as they tend to include the key issues raised in these other documents. The four white papers straddle the $9 / 11$ period and provide an indication of any change in policy approach that may have occurred during this time. The documents dealing specifically with the issue of security from 1999 and 2005 also provide insight into DfID's stance towards security post 9/11. The paper on failed states from 2005 is important as it represents the UK's growing concern with the security and development challenges posed by failed states. The 2011 DfID document is included because it is the first development policy statement of the coalition government elected in 2010. The collaborative documents from DfID, the FCO and the MoD from the years 2003 and 2004, covering the establishment of Global Conflict Prevention Pools by the UK government, are also included in the sample. In addition to these two documents, the collaborative document from 2011, Building Stability Overseas, is also included. These three documents are important as they represent the articulation of the "whole of government' approach and set out the UK's vision for conflict prevention. The UK government documents on national security from 2008 and 2010 are important for 
providing a broader picture of UK security policy and how it incorporates development issues. Whilst review documents of DfID's policy by third parties are of interest and were consulted for background, the aim of these analyses is to examine how DfID communicates its policy to the public, its peers and other parts of UK government. As result only direct DfID discourse is used and review documents are not included in the analysis. Similarly for MoD documents and National Security Strategies only the documents themselves are included rather than third party reviews. Below are the findings of a content analysis of these documents

\section{Bringing security in: a content analysis of UK security and development policy}

Table 2 Words for Content Analysis

\begin{tabular}{|c|c|c|}
\hline $\begin{array}{l}\text { Washington } \\
\text { Consensus Terms }\end{array}$ & $\begin{array}{l}\text { Post-Washington } \\
\text { Consensus Terms }\end{array}$ & $\begin{array}{l}\text { Security- } \\
\text { Development } \\
\text { Nexus Terms }\end{array}$ \\
\hline $\begin{array}{l}\text { Liberalisation } \\
\text { Deregulation } \\
\text { Privatisation } \\
\text { Global market } \\
\text { Private Sector } \\
\text { Basic needs }\end{array}$ & $\begin{array}{l}\text { Poverty } \\
\text { Institutions } \\
\text { Governance } \\
\text { Inequality } \\
\text { Human rights } \\
\text { Civil Society }\end{array}$ & $\begin{array}{l}\text { Security } \\
\qquad \begin{array}{l}\text { Human } \\
\text { Security }\end{array} \\
\text { Conflict } \\
\text { Terrorism } \\
\text { Failed States } \\
\text { Stability } \\
\text { Radicalism }\end{array}$ \\
\hline
\end{tabular}

This section presents a content analysis of UK development and security documents from the period of 1997 to present day. This content analysis applies a framework, which focuses on key words associated with three main trends in development policy over the past 30 years; the Washington Consensus, the Post-Washington Consensus and the Security-Development Nexus. The key words chosen for this framework are shown in Figure 1 above. The purpose of this is to examine the significance of the emergence of security in development policy in comparison with other major trends in development thinking over the past number of decades. This allows a comparison between the three trends at two levels: both within documents and across time. In this way the content analysis investigates whether the UK's development policy has shifted over time. The findings of this content analysis reveal three key results: 1) consistently low engagement with the Washington Consensus; 2) an increase in the security frame within development policy; and 3) significantly, a low count of development terms, either Washington Consensus or post-Washington Consensus, in 
collaborative documents between DfID and other government agencies. This may indicate that, in merging security and development policy, the UK has brought security issues into development policy to a far greater extent than it has brought development considerations into security policy. This is consistent with arguments in the literature about the securitisation of aid (Abrahamsen, 2004, 2005; Duffield, 2005, 2006,2010 ) and is counter to claims in the literature of a mutually reinforcing relationship between the two (Stewart, 2004; Picciotto, 2004).

Figure 1 Bar Chart of Grouped \% Values

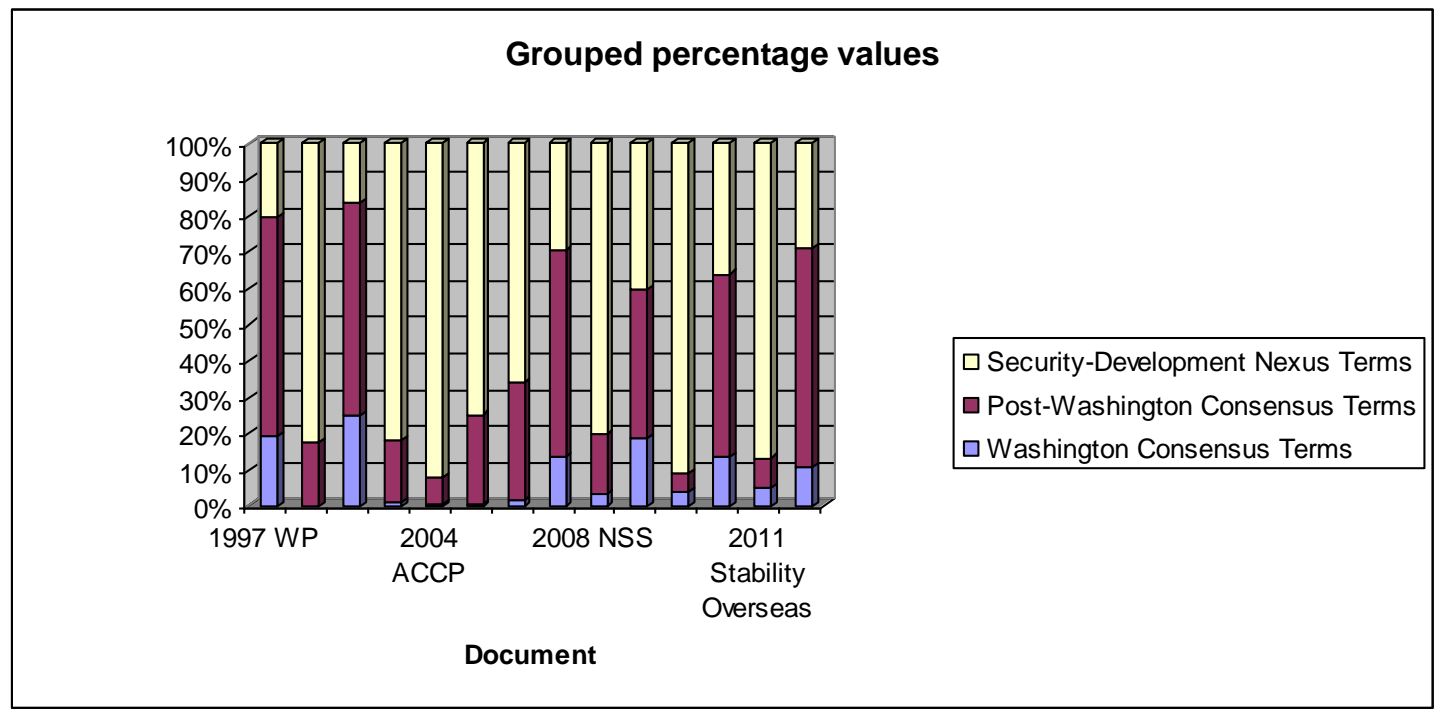

Strong engagement with the Post-Washington Consensus

Table 3 shows the total word count for each document and Table 4 shows this value expressed as a percentage of words counted for each document in order to allow comparison across documents. Table 5 groups together these percentage values to give a total for each frame. As can be seen in Figure 2, the overall percentage of words associated with the Washington Consensus is consistently low over the chosen period, in particular post-9/11. In DfID's White Papers the percentage is relatively high in 1997 at $18 \%$, this increases to $25 \%$ in the 2000 White Paper, but declines thereafter to $14 \%$ in 2006, $18 \%$ in 2009 and $10 \%$ in the 2011 document. The national security documents, the collaborative documents, and the security documents published by DfID do not contain a large percentage of Washington Consensus terms. From zero mentions in the 1999 DfID document on poverty and security to a high of $4 \%$ in the 2011 paper on stability overseas, the use of these terms is consistently low outside of DfID's White Papers. In addition to this the use of terms associated with the post-Washington Consensus remains consistently high in DfID's White Papers, staying at around $60 \%$ for 1997, 2000 and 2006, dropping to $40 \%$ in 2009 and 
increasing again to $52 \%$ in 2011, as can be seen in Table 4. This indicates a strong commitment to the principles of the post-Washington Consensus by DfID and these types of words have the highest level of any of the 3 groups of words in DfID's documents on broader development policy. In particular, the word poverty is used with consistently high frequency, as can be seen in Table 3. This demonstrates that, from the beginning of this sample in 1997, DfID had little engagement with the Washington Consensus approach in its policy and had strong engagement with the post-Washington Consensus perspective. This trend continued over the period, and is most pronounced post-9/11. Whilst the move away from the Washington Consensus holds across all the documents in this sample, the move towards the post-Washington Consensus does not, and the difference in patterns across these documents reflects the complexities of the UK's development policy.

\section{Merging Security and Development}

A second pattern that emerges is the increase in the use of terms associated with the merging of security and development. As can be seen in Table 4, the pre-9/11 White Papers have 20\% and $16 \%$ in 1997 and 2000 respectively, post-9/11 this rises to $29 \%$ in $2006,40 \%$ in 2009 and $37 \%$ in 2011 . As noted above, despite this increase, terms associated with merging security and development are still used in lower numbers than post-Washington Consensus terms in DfID's documents on broader development policy. However, as can be seen in Table 4, in the two documents on security that DfID published in 1999 and 2005, terms associated with merging security and development are used in far greater frequency than those associated with the postWashington Consensus. This is understandable for documents dealing specifically with the inclusion of security issues in development policy, with security being the main focus the counting of words is bound to be skewed towards terms associated with these issues. However, the pattern of words for the 2005 fragile states strategy paper is revealing. Again the count of $65 \%$ for security associated words is misleading as the term fragile states counts for $47 \%$ of words counted in that document as can be seen in Table 4. However, terms associated with security are still used in large frequency. This document, together with the 1999 and 2005 DfID security strategies is indicative of the wider pattern that also emerges in the collaborative documents where DfID does not show the same level of commitment to long-term development concerns when it engages with merging security and development. This can be seen in 
broader UK development policy in the collaborative documents between DfID, FCO and MoD.

Also of significance is the emergence of new terms following 9/11. As Table 3 shows, the words 'failed state' and 'radicalisation' do not appear before 9/11. Similarly, 'terrorism' appears only once in the 2000 white paper and not at all in the 1997 white paper and the 1999 security document. These three terms are then used in increasing numbers after 9/11 across both DfID, collaborative and government documents, as can be seen in Table 3. The emergence of these three terms, even though they represent a small percentage, is significant in that they reflect security concerns of the WoT - Islamic extremism that emerges from failed states and leads to terrorist attacks. The use of these terms suggests a strong engagement with hard security concerns in the UK's development policy. The manner in which these terms are used is examined in greater detail in the discourse analysis section.

\section{Marginalisation of Development in Collaborative Documents}

The three collaborative documents between DfID, FCO and MoD in this sample show a heavy focus on terms associated with security and a marginalisation of terms associated with development. As Table 4 shows, the 2003 document on the establishment of the Global Conflict Prevention Pool (GCPP) ${ }^{4}$ uses post-Washington Consensus terms in $17 \%$ of cases and security terms in $82 \%$ of cases. Similarly, the 2004 document on the establishment of the African Conflict Prevention Pool (ACPP) ${ }^{5}$ only uses post-Washington Consensus terms in $8 \%$ of cases and security terms in $92 \%$ of cases. This suggests that while DfID is involved in these collaborations, there is little room made for development policies that act as long-term solutions to conflict within these documents. For example, the 2004 ACPP document does not mention human rights or inequality, two issues that have been highlighted more broadly as key to resolving the underlying causes of conflict (see for example UN, 2005: 5; OECD, 2007). Similarly the 2011 document on creating stability overseas, issued by the coalition government, gives far greater weight to security issues, as can be seen in

\footnotetext{
${ }^{4}$ The Global Conflict Prevention Pool was a collaborative body set up to deal with conflict through close collaboration between DfID, the FCO and the MoD

${ }^{5}$ The Africa Conflict Prevention Pool was a collaborative body set up to deal specifically with conflict in Africa through close coordination between DfID, the FCO and the MoD. Both bodies have been consolidated into one institution called the Conflict Pool.
} 
Table 4, with $9 \%$ for post-Washington Consensus terms and $88 \%$ for security terms. In addition, as Table 3 shows, the term 'terrorism' is mentioned on $5 \%$ of occasions which is in greater frequency than either 'poverty', 'institutions', 'governance', 'inequality', 'human rights' or 'civil society'.

When examining how security has influenced development policy, it is also useful to examine the reverse - how development thinking has influenced security policy. Looking at the 2008 National Security Strategy (NSS) post-Washington Consensus terms are used $16 \%$ of the time compared to $80 \%$ of the time for security terms. In the 2010 NSS this falls to $10 \%$ for post-Washington Consensus terms and increases to $90 \%$ for security terms. This suggests that development policies espoused by DfID have not had a big impact on other government agencies. This point is important as it was assumed by commentators (Stewart, 2004; Picciotto, 2004) that the collaboration between DfID and other agencies and the broader 'whole of government approach' that has been a feature of UK foreign policy over the past decade would result in greater attention for development issues. Merging security and development in DfID policy discourse

As demonstrated above, three key patterns that emerge are: the consistent use of terms associated with the post-Washington Consensus, the increase in the use of terms associated with the merging of security and development - including terms associated with hard security in the WoT; a marginalisation of the use of development terms in collaborative documents and no real impact of development terms in security documents. These findings are important because while DfID has given more space to security in its development policy there has not been the reverse increase in development concerns in security policy. In addition, collaborative documents involving DfID, FCO and MoD give less attention to long-term development policies and greater attention to security issues. These findings suggest that, in collaboration with other government agencies and in the broadening of development to other foreign policy areas, long-term development policies are not given the same attention as traditional security concerns. Contra to the claims of commentators that a broadening of development to include security issues would developmentalise security, instead development appears to have become securitised (Picciotto, 2004; Stewart, 2004). How has this come about? There are limitations to counting words as a means of analysis, as outlined above, and so it is necessary to take a more in depth 
look at the way in which these words are used through a discourse analysis. In addition to this interview data is drawn on to examine the extent to which policy discourse is consistent with development policy. This is the focus of the next part of this paper which, through a discourse analysis of these same documents together with interview data, uncovers three distinct phases in DfID's securitisation of its development policy.

\section{Merging Security and Development: Three phases of DfID engagement with security}

As demonstrated in the above section, the UK has engaged with the language of security increasingly over the period of 1997-2012. In addition, it has introduced words associated with the WoT such as 'terrorism', 'fragile states' and 'extremism' into its policy discourse. A closer analysis of this merging of security and development reveals three phases of engagement with security in DfID's development policy documents. The first phase can be described as 'security as an exception' and covers the pre-9/11 documents where security is tentatively dealt with and a number of restrictions are placed on DfID's involvement with it. The second phase can be called 'security as a core development problem.' This emerges post-9/11 and involves a heavy engagement with security putting it at the heart of DfID policy. The third phase can be called 'national security as a development issue' and emerges in the late 2000s and involves the introduction of UK national security as a development problem. The three phases represent three crude time periods: pre-9/11, post-9/11 and The Conservative party assume responsibility for DfID. Each successive phase contains elements of the previous one and while they are not discreet analytical categories, they are a way of tracing the evolution of security in DfID's policy. These phases are also marked by changes in who is the referent object of security. Within these phases both the UK and ordinary citizens are framed as being the benificiaries of DfID's actions on security. Within this change, two different conceptions of security are drawn on: hard security concerns associated with the WoT and broader security concerns associated with human security. As mentioned above, the concept human security is contested in the academic literature. It is beyond the scope of this article to resolve this debate. It is argued that the focus on security for the individual rather than the state is the common factor in most understandings of human security 
(Chandler, 2012: 214). Therefore, for the purposes of analysing UK policy discourse, when security is framed as focusing on the well-being of individuals in developing states it is argued that it is drawing on the discourse of human security rather than conventional state-centric definitions of security. David Chandler focuses on the idea of 'resilience' as key to human security which “enables an analysis of human security that does not rely on the 'word search' approach favoured by authors who point to the rise or decline of human security merely in terms of the use of the term in official documents and reports" (2012: 216). As noted above, the count for the use of the term 'human security' is low across all documents and as such, the content analysis does not adequately capture DfID's engagement with the concept. Similar to the above quote, this article addresses this issue by taking the understanding of human security in terms of framing ordinary people as the referent object of security which allows a deeper analysis of the issue than the above content analysis. In bringing national security into development policy, DfID brings these two different conceptions of security together through a series of arguments around common interest between the global South and the Global North. This section will examine these three phases of engagement in detail. Following this is an examination of the arguments around common interests that are constructed to link development spending to UK national security.

\section{1) Security as an exception}

When security is introduced into DfID's policy discourse in the late 1990s there are clear limitations placed on its involvement in this area. It is made clear that the focus of security is people in the developing world and development involvement in security is only to meet that end "The poor must benefit (from DfID's involvement in security) and DFID will assess this before any activity can proceed." (DfID, 1999: 3). The limits for DfID's involvement in security are set at the poorest being the focus of the policy and sufficient civilian oversight of the armed forces (DfID, 1999: 2) due to a recognition that security forces in developing countries are often a source insecurity for the poorest and most vulnerable "The poor worldwide also tend to be very distrustful of existing police and criminal justice systems. Far from protecting people from violence, too often elements within the police and justice systems are themselves sources of violence and abuse." (DfID, 2000: 23). In addition to this, DfID distances 
itself from getting involved in traditional hard security concerns for fear of development goals being subverted (DfID, 1999: 6). As highlighted previously in Table 3, there is only one reference to 'terrorism' prior to $9 / 11$. It is identified as a problem for DfID because of how it affects people in the developing world (DfID, 2000: 7). In this phase, even when terrorism is mentioned, it is only in reference to the wellbeing of developing states, and the security of the UK is not a consideration. In interview, Clare Short - DfID's Secretary of State for International Development from 1997-2003, revealed that DfID became involved in conflict situations in the Balkans and Sierra Leone before it had formulated a clear policy. This could be seen as the formative stage for merging security and development in UK policy. In 2000 the Africa Conflict Prevention Pool and the Global Conflict Prevention Pool were established as a means of coordinating funding between DfID, the MoD and the FCO in order to resolve conflict through combined efforts. Coordinating funding in this way allowed DfID to get involved in activities deemed to be outside of official ODA limits, such as military and police reform programmes (Independent Commission for Aid Impact, 2012: 2). As a result, policy was formulated after these interactions and clear limits were placed upon it in order to maintain a clear focus on poverty reduction ${ }^{6}$. In particular, the intervention in Sierra Leone was influential in shaping top level UK development policy through the influence of actors on the ground and trends first noted there "such as the privatisation and militarisation of emergency assistance" were later seen in Iraq and Afghanistan. (Schümer, 2008: 9). For example, the supply by DfID of equipment to Sierra Leonean police as part of the reform process came out of consultations in country (Horn et al., 2006: 115). From this perspective DfID's engagement with security arose out of involvement in specific events rather than from an existing policy position. As a result clear limits are placed on DfID's involvement in security to limit it to specific instances where poverty reduction is still prioritised.

Within this frame, even a hard security concern such as terrorism is presented as a problem for DfID because of how it impacts on ordinary people in the developing world, not because of how it impacts on the security of states in the developed world “...terrorism and the illicit drugs trade; the spread of health pandemics like

\footnotetext{
${ }^{6}$ Telephone interview Clare Short, 23/1/2013
} 
HIV/AIDS; and environmental degradation - are caused or exacerbated by poverty and inequality" (DfID, 2000: 7). This understanding of security is consistent with the concept of human security where the focus is on the rights of individuals in developing countries, and where there is a recognition that the state can be a source of insecurity for its own citizens. In this phase security is at the periphery of development policy and is focused solely on people in the developing world. The developing world is not portrayed as a source of insecurity for or a threat to the developed world. Elements of this understanding persist within subsequent frames.

\section{2) Security as a core development problem}

While DfID makes continuous reference to the human security approach of the earlier phase and to the restrictions placed on DfID's involvement in security, this second phase still sees security brought to the core of DfID policy discourse. There are repeated assertions that poverty reduction will not be subordinate to security concerns of counterterrorism (DfID, 2005: 5, 6, 13) and that the poorest people rather than states will remain the focus of DfID's policy (DfID, 2005: 5; 2009: 75). In this second phase of merging security and development, security is brought from the periphery into the core of UK development policy. In addition to this the definition of security is widened out to include issues of terrorism and religious extremism. Moreover, the referent object of security is now global rather than just individuals in developing countries and the developing world is represented as a source of insecurity for the developed world. The issue of UK National security as a development concern is strongly suggested but not explicitly stated

In the documents published after $9 / 11$ security is brought into the core of DfID's development policy discourse rather than something that is exceptional and contingent. This is most evident in the 2005 DfID security document:

\footnotetext{
"Wars kill development as well as people. The poor therefore need security as much as they need clean water, schooling or affordable health. In recent years, DFID has begun to bring security into the heart of its thinking and practice.” (DfID, 2005: 3)
} 
Here security is placed at the same level as health, education and access to clean water. This shows a dramatic change from the restrictions placed on DfID's involvement in security prior to $9 / 11$. In this same document the definition of security includes threats such as terrorism and extremism. While the human security agenda sought to elevate development issues to the same level as security issues, instead DfID has adopted security, now defined as including hard security problems, as a development problem on the same level as education and healthcare. Whereas advocates of human security distinguished security problems facing states from those facing individuals in order to prioritise the latter, here DfID brings these interests together. This position is reaffirmed with the assertion that "security is a precondition for development" (DfID, 2006: 45).

In addition to this adoption of security as a core development problem, the definition of security is expanded to include threats associated with the WoT such as terrorism and religious extremism (DfID, 2005: 12; 2006: 47; 2009: 5). For example "violent conflict and insecurity can spill over into neighbouring countries and provide cover for terrorists or organised criminal groups" (DfID, 2006: 45). In this way the argument is constructed that terrorism is caused by poverty, therefore fighting poverty will fight terrorism. In addition, the argument is made that terrorism impacts on developing countries directly, therefore fighting terrorism can help to fight poverty. At this stage, the issue of development as important for UK National Security is strongly suggested but not stated explicitly. This is evident in the way that fragile states are discussed. The argument is made that they are a development problem because they suffer from poverty, thereby providing the space for terrorism and extremism to develop and therefore they are a global security threat as well as a development problem (DfID, 2005: 5 2006: 7; 2009: 6). When fragile states are referred to the examples given are Afghanistan, Pakistan and Somalia and they are referenced in terms of the danger they pose due to attacks on London, Mumbai and New York (DfID, 2006: 7, 47; 2009: 6). This is most evident in the following quote: "State failure and radicalisation such as in Afghanistan and Pakistan has brought terror to New York and London as well as Mumbai and Islamabad" (DfID, 2009: 1617). Here fragile states in the developing world are represented as a threat to security in the West. This is revealing as fragile states that do not represent a terrorist threat, for example Haiti or Niger, are not given space in DfID's policy documents. As Table 
1 shows, coinciding with this shift in discourse, DfID's spending in so-called fragile or failed states and strategic states in the war on terror has increased significantly over the period under investigation. The frontline WoT states of Iraq, Afghanistan and Pakistan are consistently among DfID's top 10 recipients following 2001. In addition states identified as conflict affected and fragile such as the Democratic Republic of Congo and Sudan are also among DfID’s top 10 recipients over this time.

\section{3) National Security as a development issue}

In the third phase in the merging of security and development, UK National security is highlighted as a development concern for DfID. This issue is raised directly for the first time in the 2008 National Security Strategy "we are also looking at the ways in which our overseas aid policy contributes to the security of the citizens' countries and regions concerned, and also to our own national security" (UK Cabinet Office, 2008: 52). This is the first direct reference to UK national security in this sample of documents. This is not brought into development policy until after the election of the Coalition government in 2010: "their (fragile states) instability has the potential to affect our own security" (DfID, 2011b: 59); and again "Aid is vitally important to tackling the root causes of those global problems - disease, drugs, terrorism, climate change - that threaten our own future" (DfID, 2011a: 2). In the previous phase, when the issue of global security as a development problem was raised it was also balanced out by assertions that development aid would not be overtaken by these concerns. There was a recognition that there may be a conflict of interest between the two agendas of UK national security and overseas development. However, in this third phase the issue of UK national security is adopted unproblematically. It is still the case that contradictions may arise when coordinating development and security agendas $^{7}$, so the absence of this in policy discourse is an omission, rather than an indication that the issue has been resolved and no longer worth discussing. It is asserted that the national security interests of the UK and the interests of people in developing countries are the same and are mutually reinforcing "Helping the world's

\footnotetext{
${ }^{7}$ Telephone interview with Anonymous DfID official 2, 7/11/2012; Personal interview with Anonymous DfID Kenya official 1, 17/6/2013
} 
poorest people is not only the right thing to do, it also makes sense for us here in Britain. Development makes a real difference to problems which might otherwise arrive on our streets, such as drugs, extremism and disease." (DfID, 2011a: 36). The centrality of National security in DfID policy is justified through a series of claims of common interest.

The claim of common interest between development and security in the global South and UK national security is strongly adopted and everything within this is assumed to reinforce this common objective. As a result there is now no attempt to offer reassurances that development goals will not be sidelined. This is most evident in the consolidated focus on fragile states. A commitment has now been made to spend $30 \%$ of UK overseas aid on fragile states (DfID, FCO \& MoD, 2011: 2). The logic presented is that a vast number of poor people live in these states, and so spending in

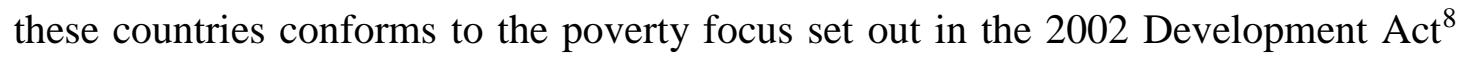
"sustainable development includes any development that is...prudent having regard to the likelihood of its generating lasting benefits for the population of the country or countries in relation to which it is provided" (UK Government 2002: 2). In addition to this, these states are described as "ungoverned spaces" from which terrorism, religious extremism, migration and trade in illicit narcotics flow and so resolving these issues contributes to UK national security (DfID, FCO, MoD, 2011: 8; DfID, 2011a: 36). Fragile states are the sites where development and national security interests of poverty, poor governance, terrorism, criminality and extremism all overlap.

Chandler (2012: 220) has argued that during this period there has been a shift in security policy from imposing solutions from the outside to support for agency within recipient countries to overcome security problems. Pugh et al. (2013) take this further and argue, through research focused mostly on interventions rather than mainstream development policy, that the coalition government has overseen a shift to the 'developmentalisation of security.' The assertion is that human security is now in the mainstream, and the evidence offered to support this is that NGOs have expressed approval for this rather than objecting to it as may be expected if it was subverting

\footnotetext{
${ }^{8}$ The 2002 International Development Act reformed UK aid policy to make sustainable development the explicit goal of aid and to remove the practice of using aid to further UK commercial interests.
} 
development (Pugh et al., 2013: 199). Whilst this argument may hold for the intervention in Libya, the above content and discourse analyses show at the level of policy discourse UK security documents have consistently low engagement with core development ideas such as poverty. This is consistent over this period of time and has not changed for the most recent security documents published under the Coalition government, as Table 5 shows.

This merging interests approach is also clearly evident in interviews conducted with DfID officials. The clearest example is in an interview with Andrew Mitchell, Secretary of State for International Development from 2010-2012:

Security is not only achieved by armies and navies. It's also achieved by training the police in Afghanistan and building up governance structures in the Arab Spring countries and getting girls to school in the Horn of Africa. These are things which are paid for by development spending but they contribute very much to our security in the end. If you follow that logic you can understand that development and defence and diplomacy all go together 9

UK security is framed in terms of governance and education and the argument is made that development spending on these issues will benefit all sides, both within the UK Government and in the developing world.

This claim to merging interests between development in the South and security in the North heavily draws on a language of human security. Interviews with DfID officials make repeated references to education as a security agenda ${ }^{10}$. The implication is that the UK now sees security in terms of broader problems relating to the welfare of individuals in developing countries rather than in a zero sum way of conventional state-centric security. This is reinforced by repeated references to the individuals in developing countries as the referent objects of security by interviewees, for example: "security, health, food crises, you know water hygiene, nutrition the well-being of people, these are all part of our policy"11 This human security focus on the welfare of

\footnotetext{
${ }^{9}$ Telephone interview Andrew Mitchell, 29/1/2013

${ }^{10}$ Telephone interview with Anonymous DfID official 1, 6/11/2012; Telephone interview with Anonymous DfID official 2, 7/11/2012

${ }^{11}$ Telephone interview with Anonymous DfID official 1, 6/11/2012 also Telephone interview with Anonymous DfID official 2, 7/11/2012; Telephone interview with Anonymous DfID official 3, $23 / 4 / 2013$
} 
the individual notwithstanding, the state remains a principle referent object of security. The focus on fragile states is with the intention of rebuilding the state. In addition to this, the aim is to ensure regional stability. For example, the importance of supporting Ethiopia and Kenya in order to contain the fallout from Somalia is emphasised by DfID officials ${ }^{12}$. In this third phase of merging security and development, the connection between the development needs of poor countries and the security of the UK is treated as unproblematic and based on common sense.

A key issue is whether security policy discourse has been influenced by development thinking. The content analysis, above, suggests that it has not. Similarly, interviewees assert that development policy has not had a significant impact of security policy at this time. ${ }^{13}$ Whilst the MoD manuals on counterinsurgency do refer to winning 'hearts and minds' it is in the context of facilitating more effective military operations (MoD, 2009a: 115, CS5-1), or “populations' perceptions of their government" (MoD, 2009b: 27) rather than addressing long-term development. Whilst not as overtly military focused as the US approach: "“'Hearts" means persuading people that their best interests are served by [counterinsurgency] success. "Minds" means convincing them that the force can protect them and that resisting is pointless" (US DoD, 2006: 15), it still does not represent a significant engagement with long-term development.

Where policy has changed over this period is that more space has opened up for DfID to get involved in issues of conflict and security during this third phase. Interviewees have asserted that framing national security as a function of development aid has opened up more space for DfID to address security issues that affect ordinary citizens and has made a stronger case for development within UK government ${ }^{14}$. Examples of this can be seen in the five year funding commitment for programmes aimed at increasing access to safety and justice for women and girls in Ethiopia (DfID 2011c: 14). One interviewee described it as opening up space for programmes that addressed issues of conflict and security and also allowing policy activity in parts of the country that DfID had previously not been willing or able to operate in such as the Somali

\footnotetext{
12 Telephone interview with Anonymous DfID official 1, 6/11/2012; Telephone interview with Anonymous DfID official 2, 7/11/2012; Telephone interview with Anonymous DfID official 3, 23/4/2013.

${ }^{13}$ Telephone interview with anonymous DfID official 3, 23/4/2013

${ }^{14}$ Personal interview with Anonymous DfID Ethiopia official 1, 10/6/2013 ; Personal interview with Anonymous DfID Kenya official 1, 17/6/2013
} 
region. ${ }^{15}$ Similarly, in Kenya DfID has initiated programmes aimed at conflict mediation in the North Eastern region which has experienced significant conflict. ${ }^{16}$ In both countries interviewees expressed the view that the discourse representing development as a national security issue has made it easier to make the case for getting involved in these programmes. ${ }^{17}$

security and justice programming within development plays a bigger part in the bigger national security picture. Which actually makes it easier for us to get that message back up through government because of the higher priority than it was with the last government who didn't have that kind of narrative going on. ${ }^{18}$

Interestingly, as DfID has become more involved in security focused programmes, its contribution to the Conflict Pools has shrunk. For example, DfID went from funding 35\% of the Conflict Pool budget in 2009 to just 5\% of the budget in 2011 (Independent Commission for Aid Impact, 2012: 4). As the Conflict Pools were established to allow DfID to get involved in security issues, perhaps the need for this coordination has lessened as security has become prominent in DfID discourse, DfID spending has shifted to conflict affected states and DfID has initiated programmes aimed at preventing and mediating conflict. This suggests that perhaps the strong engagement with security goes further than DfID discourse to its policy practice too. The merging of security and development in UK policy has given DfID renewed purpose in contributing to national security. This has resulted in greater funding for DfID, during a time when other departments have endured successive budget cuts. In addition, it has allowed an extended mandate to get more deeply involved in areas related to conflict resolution that was previously not possible. As a result there is a clear interest for DfID to sustain this closer connection between security and development making its enthusiasm for this policy change understandable.

\footnotetext{
${ }^{15}$ Personal interview with Anonymous DfID Ethiopia official 1, 10/6/2013

${ }^{16}$ Personal interview with Anonymous DfID Kenya official 1, 17/6/2013

${ }^{17}$ Personal interview with Anonymous DfID Kenya official 1, 17/6/2013

${ }^{18}$ Personal interview with Anonymous DfID Ethiopia official 1, 10/6/2013
} 


\section{Conclusion}

This paper argues that DfID has brought UK national security into the core of its policy discourse through a gradual process over this period by linking poverty and instability in the developing world to threats to UK national security such as terrorism and religious extremism. DfID has justified this shift through claims of common interest between development for people in the global South and security for the UK by drawing on the concept of human security wherein development is offered as a solution to national security problems. This is demonstrated in two ways: the increasingly high word count for terms associated with security in policy documents and the three different phases of engagement with security which are revealed by the discourse analysis and interviews. This involves a shift from an initially cautious and restricted approach to one which places UK national security as a development priority. This is done through a series of arguments claiming a common interest between development in the developing world and security in the developed world. These draw on the main principles of human security, particularly the focus on the individual as the referent object of security, in order to make these claims. Coinciding with this shift in discourse is a prioritisation of fragile states in aid flows and DfID involvement in specific programmes aimed at addressing security concerns. The connections made between poverty and insecurity of people in the developing world, state fragility and UK national security open up space for DfID within its policy discourse to argue for engagement in areas beyond its principle remit of poverty reduction. The benefits of this for DfID have been a bigger budget and an extended remit to engage with issues of conflict and security. As a result, it is perhaps understandable that DfID has bought in to the merging of security and development.

\section{List of References}

Abrahamsen, Rita. 2004). A Breeding Ground for Terrorists? Africa and Britain's 'War on Terrorism'. Review of African Political Economy 31(102): 677-684.

Abrahamsen, Rita. 2005. Blair's Africa: The Politics of Securitization and Fear. Alternatives 30(1): 55-80.

Bachmann, Jan \& Jana Hönke. 2010. 'Peace and Security'as Counterterrorism? The Political Effects of Liberal Interventions in Kenya. African affairs 109(434): 97-114. 
Beall, Jo, Thomas Goodfellow, and James Putzel. 2006. Policy Arena. Introductory Article on the Discourse of Terrorism, Security and Development. Journal of International Development, 18(1): 51-67.

Carmody, Pádraig. 2005. Transformation Globalisation and Security: Africa and America Post-9/11. Africa Today 52(1): 97-120.

Carmody, Pádraig. 2011. The New Scramble for Africa. Cambridge: Polity Press.

Denney, Lisa. 2011. Reducing Poverty with Teargas and Batons: the Security Development Nexus in Sierra Leone. African Affairs, 110(439): 275-294.

DfID. 1997. Eliminating World Poverty: A Challenge for the 21st Century, White Paper on International Development. London: Department for International Development.

DfID. 1999. Poverty and the Security Sector, Policy Statement. London: Department for International Development.

DfID. 2000. Eliminating World Poverty: Making Globalisation Work for the Poor. White Paper on International Development. London: Department for International Development.

DfID. 2005. Fighting poverty to build a safer world. A strategy for security and development. London: Department for International Development.

DfID. 2006. Eliminating World Poverty: Making Governance Work for the Poor. White Paper on International Development. London: Department for International Development.

DfID. 2009. Eliminating World Poverty: Building Our Common Future. White Paper on International Development. London: Department for International Development. .

DfID. 2011a. UK aid: Changing Lives, delivering results. London: Department for International Development.

DfID. 2011b. Multilateral Aid Review Ensuring maximum value for money for UK aid through multilateral organisations. London: Department for International Development.

DfID. 2011c. DfID Ethiopia Operational Plan 2011-2015. London: Department for International Development.

DfID, FCO and MoD. 2003. The Global Conflict Prevention Pool: A Joint UK Government Approach to Reducing Conflict. London: Department for International Development.

DfID, MoD and FCO. 2004. The Africa Conflict Prevention Pool: An Information Document. Department for International Development: London. 
DfID, FCO and MoD. 2011. Building Stability Overseas Strategy. London: DfID, FCO and MoD.

Duffield, Mark. 2005. Getting Savages to Fight Barbarians: Development, Security and the Colonial Present. Conflict, Security and Development 5(2): 141-159.

Duffield, Mark. 2006. Human Security: Linking Development and Security in an age of Terror. New Interfaces between Security and Development: Changing Concepts and Approaches, German Development Institute, Study No.13: 11-38.

Duffield, Mark. 2010. The Liberal Way of Development and the Development Security Impasse: Exploring the Global Life-Chance Divide. Security Dialogue 41(1): 53-76.

Duffield, Mark and Nicholas Waddell. 2006. Securing Humans in a Dangerous World. International Politics, 43(1): 1-23.

Ellis, Stephen. 2004. Briefing: the Pan-Sahel Initiative. African Affairs 103(412): 459-464.

Fitz-Gerald, Ann M. 2006. Addressing the Security-Development Nexus: Implications for Joined-Up Government. New Interfaces between Security and Development: Changing Concepts and Approaches. Bonn: German Development Institute, Study No.13: 107-126.

Henk, Dan. 2005. Human Security: Relevance and Implications. Parameters 35(2), Summer: 91-106.

HM Government. 2010. Securing Britain in an Age of Uncertainty: The Strategic Defence and Security Review. London: The Stationary Office Ltd.

Horn, Adrian, Funmi Olonisakin and Gordon Peake. 2006. United Kingdom-led Security Sector Reform in Sierra Leone. Civil Wars, 8(2): 109-123.

Howell, Jude. 2010. National security concerns continue to dictate Britain's government aid and development agendas' London School of Economics blog post, October $4^{\text {th }}$ 2010. http://blogs.lse.ac.uk/politicsandpolicy/2010/10/04/nationalsecurity-concerns-continue-to-dictate-britain \%e2\%80\%99s-government-aid-anddevelopment-agendas/ (Accessed 27/3/2014)

Howell, Jude and Lind, Jeremy. 2009. Changing Donor Policy and Practice in Civil Society in the Post-9/11 Aid Context. Third World Quarterly 30(7): 1279-1296.

Human Security Centre, University of British Columbia, 2005. Human Security Report: War and Peace in the 21st Century. Oxford: Oxford University Press.

Independent Commission for Aid Impact. 2012. Evaluation of the Inter-Departmental Conflict Pool. London: Independent Commission for Aid Impact. 
Ingram, Alan. 2007. HIV/AIDS, Security and the Geopolitics of US-Nigerian

Relations. Review of International Political Economy 14(3): 510-534.

Institute for Democracy and Democracy and Electoral Assistance. 2006. Democracy, Conflict and Human Security Policy Summary: Key Findings and Recommendations. Stockholm: International IDEA.

International Commission on Intervention and State Sovereignty International. 2001. The Responsibility to Protect. Ottawa: Development Research Centre.

Krogstad, Erland G. 2012. Security, development, and force: Revisiting police reform in Sierra Leone. African Affairs, Vol. 111, No. 443, pp. 261-280.

MoD. 2009a. British Army Field Manual Volume 1 Part 10: Countering Insurgency. London: MoD

MoD. 2009b. British Military Publication "Security and Stabilisation: the Military Contribution,” Joint Doctrine Publication 3-40 (JDP 3-40). London: MoD

Newman, Edward. (2001). Visions of International Studies, Human Security and Constructivism', International Studies Perspectives 2(3): 239-251.

Noxolo, Patricia. 2012. One world, big society: a discursive analysis of the Conservative green paper for international development. The Geographical Journal, 178(1): 31-41.

OECD. 2007. The OECD handbook on security sector reform (SSR): Supporting security and justice. Publications de l'OCDE.

Picciotto, Robert. 2004. Aid and conflict: the policy coherence challenge. Conflict Security and Development, 4(3): 543-562.

Pugh, Jonathan, Clive Gabay and Alison J. William. 2013. Beyond the securitisation of development: The limits of intervention, developmentalisation of security and repositioning of purpose in the UK Coalition Government's policy agenda. Geoforum , 44: 193-201.

Ritchie, Nick. 2011. Rethinking security: a critical analysis of the Strategic Defence and Security Review. International Affairs, 87(2): 355-376.

Shannon, Róisín. 2009. Playing With Principles in an Era of Securitized Aid:

Negotiating Humanitarian Space in Post-9/11 Afghanistan. Progress in Development Studies 9(1): 15-36.

Stern, Maria and Öjendal, Joakim. 2010. Mapping the Security-Development Nexus: Conflict, Complexity, Cacophony Convergence? Security Dialogue 41(1): 5-30. 
Stewart, Frances. 2004. Development and security. Conflict Security and Development, 4(3): 261-288.

UK Cabinet Office. 1999. Modernising Government. London: The Stationary Office.

UK Cabinet Office. 2008. The National Security Strategy of the United Kingdom: Security in an Interdependent World. London: Cabinet Office.

UK Government. 2002. The International Development Act 2002. London: UK Government.

UN. 2005. In larger freedom: towards development, security and human rights for all. - Report of the Secretary General. New York: United Nations.

UN. 2010. Human Security: Report of the Secretary General. New York: United Nations.

UNDP. 2004. Human development report 1994. New York: Oxford University Press.

US DoD. 2006. Department of the Army Counterinsurgency FM 3-24. Washington, D.C. : Headquarters Department of the Army

Waddell, Nicholas. 2006. Ties that Bind: DfID and the Emerging Security and Development Agenda. Conflict, Security and Development 6(4): 531-555.

Wild, Leni and Samir Elhawary. 2012. The UK's approach to linking development and security: assessing policy and practice. ODI Working Paper347. London: Overseas Development Institute.

Youngs, Richard. 2007. Fusing Security and Development: Just another Europlatitude? FRIDE Working Paper No. 43. September: 1-18. 
Table 3: Total Word Count for all Documents

\begin{tabular}{|c|c|c|c|c|c|c|c|c|c|c|c|c|c|c|}
\hline & $\begin{array}{l}1997 \text { White } \\
\text { Paper }\end{array}$ & $\begin{array}{l}1999 \\
\text { Security } \\
\text { Strategy }\end{array}$ & $\begin{array}{l}2000 \\
\text { White } \\
\text { Paper }\end{array}$ & $\begin{array}{l}2003 \\
\text { GCPP }\end{array}$ & $\begin{array}{l}2004 \\
\text { ACCP }\end{array}$ & $\begin{array}{l}2005 \\
\text { Security } \\
\text { Paper }\end{array}$ & $\begin{array}{l}2005 \\
\text { Fragile } \\
\text { States }\end{array}$ & $\begin{array}{l}2006 \\
\text { White } \\
\text { Paper }\end{array}$ & 2008 NSS & $\begin{array}{l}2009 \\
\text { White } \\
\text { Paper }\end{array}$ & $\begin{array}{l}2010 \\
\text { Security } \\
\text { Strategy }\end{array}$ & $\begin{array}{l}2011 \text { UK } \\
\text { aid }\end{array}$ & $\begin{array}{l}2011 \\
\text { Stability } \\
\text { Overseas }\end{array}$ & $\begin{array}{l}2011 \\
\text { Multilateral } \\
\text { Aid } \\
\text { Review }\end{array}$ \\
\hline \multicolumn{15}{|l|}{$\begin{array}{l}\text { Washington } \\
\text { Consensus }\end{array}$} \\
\hline Liberalisation & 9 & 0 & 12 & 0 & 0 & 0 & 0 & 3 & 1 & 2 & 1 & 0 & 0 & 0 \\
\hline Deregulation & 0 & 0 & 0 & 0 & 0 & 0 & 0 & 0 & 0 & 0 & 0 & 0 & 0 & 0 \\
\hline Regulation & 4 & 0 & 22 & 1 & 1 & 1 & 2 & 11 & 1 & 3 & 1 & 0 & 1 & 5 \\
\hline Privatization & 0 & 0 & 0 & 0 & 0 & 0 & 0 & 3 & 0 & 2 & 0 & 0 & 0 & 0 \\
\hline $\begin{array}{l}\text { Private } \\
\text { Sector }\end{array}$ & 22 & 0 & 28 & 1 & 0 & 2 & 1 & 25 & 8 & 37 & 11 & 5 & 13 & 43 \\
\hline Market & 27 & 0 & 67 & 1 & 0 & 0 & 0 & 33 & 11 & 74 & 8 & 5 & 2 & 10 \\
\hline Basic Needs & 3 & 0 & 0 & 0 & 0 & 0 & 0 & 1 & 0 & 1 & 0 & 3 & 3 & 1 \\
\hline \multicolumn{15}{|l|}{$\begin{array}{l}\text { Post- } \\
\text { Washington } \\
\text { Consensus }\end{array}$} \\
\hline Poverty & 110 & 6 & 147 & 5 & 5 & 49 & 23 & 121 & 19 & 110 & 4 & 44 & 2 & 57 \\
\hline Institutions & 33 & 2 & 73 & 12 & 8 & 12 & 17 & 35 & 37 & 44 & 11 & 2 & 3 & 64 \\
\hline Governance & 7 & 2 & 3 & 9 & 3 & 13 & 14 & 95 & 25 & 39 & 8 & 1 & 5 & 38 \\
\hline Inequality & 25 & 0 & 32 & 1 & 0 & 12 & 1 & 16 & 10 & 20 & 1 & 0 & 1 & 95 \\
\hline Human rights & 24 & 6 & 22 & 25 & 0 & 6 & 1 & 21 & 4 & 15 & 3 & 0 & 12 & 7 \\
\hline Civil Society & 6 & 3 & 21 & 9 & 6 & 2 & 5 & 28 & 5 & 34 & 1 & 2 & 10 & 63 \\
\hline \multicolumn{15}{|l|}{$\begin{array}{l}\text { Security - } \\
\text { Development } \\
\text { Nexus }\end{array}$} \\
\hline Security & 15 & 69 & 19 & 71 & 56 & 150 & 4 & 45 & 239 & 80 & 326 & 11 & 66 & 16 \\
\hline $\begin{array}{l}\text { Human } \\
\text { Security }\end{array}$ & 0 & 1 & 0 & 1 & 0 & 3 & 0 & 0 & 0 & 0 & 0 & 0 & 0 & 1 \\
\hline Conflict & 33 & 18 & 50 & 186 & 196 & 98 & 5 & 83 & 78 & 103 & 50 & 17 & 158 & 57 \\
\hline Terrorism & 0 & 0 & 1 & 5 & 1 & 25 & 4 & 5 & 103 & 7 & 79 & 1 & 11 & 0 \\
\hline Failed States & 0 & 0 & 0 & 1 & 0 & 4 & 89 & 18 & 14 & 46 & 1 & 2 & 19 & 82 \\
\hline Stability & 21 & 3 & 15 & 22 & 7 & 9 & 21 & 9 & 44 & 16 & 33 & 3 & 82 & 3 \\
\hline Radicalism & 0 & 0 & 0 & 2 & 0 & 1 & 0 & 3 & 18 & 4 & 4 & 1 & 2 & 0 \\
\hline
\end{tabular}


Table 4: Total count of words as percentage for each document

\begin{tabular}{|c|c|c|c|c|c|c|c|c|c|c|c|c|c|c|}
\hline & 1997 WP & $\begin{array}{l}1999 \\
\text { Security } \\
\text { Strategy }\end{array}$ & $\begin{array}{l}2000 \\
\text { WP }\end{array}$ & $\begin{array}{l}2003 \\
\text { GCPP }\end{array}$ & $\begin{array}{l}2004 \\
\text { ACCP }\end{array}$ & $\begin{array}{l}2005 \\
\text { Security } \\
\text { Paper }\end{array}$ & $\begin{array}{l}2005 \\
\text { Fragile } \\
\text { States }\end{array}$ & $\begin{array}{l}2006 \\
\text { WP }\end{array}$ & $\begin{array}{l}2008 \\
\text { NSS }\end{array}$ & $\begin{array}{l}2009 \\
\text { WP }\end{array}$ & $\begin{array}{l}2010 \\
\text { Security } \\
\text { Strategy }\end{array}$ & $\begin{array}{l}2011 \\
\text { UK aid }\end{array}$ & $\begin{array}{l}2011 \\
\text { Stability } \\
\text { Overseas }\end{array}$ & $\begin{array}{l}2011 \\
\text { Multilateral } \\
\text { Aid } \\
\text { Review }\end{array}$ \\
\hline \multicolumn{15}{|l|}{$\begin{array}{l}\text { Washington } \\
\text { Consensus }\end{array}$} \\
\hline Liberalisation & $2.65 \%$ & $0.00 \%$ & $2.34 \%$ & $0.00 \%$ & $0.00 \%$ & $0.00 \%$ & $0.00 \%$ & $0.54 \%$ & $0.16 \%$ & $0.31 \%$ & $0.18 \%$ & $0.00 \%$ & $0.00 \%$ & $0.00 \%$ \\
\hline Deregulation & $0.00 \%$ & $0.00 \%$ & $0.00 \%$ & $0.00 \%$ & $0.00 \%$ & $0.00 \%$ & $0.00 \%$ & $0.00 \%$ & $0.00 \%$ & $0.00 \%$ & $0.00 \%$ & $0.00 \%$ & $0.00 \%$ & $0.00 \%$ \\
\hline Privatization & $0.00 \%$ & $0.00 \%$ & $0.00 \%$ & $0.00 \%$ & $0.00 \%$ & $0.00 \%$ & $0.00 \%$ & $0.54 \%$ & $0.00 \%$ & $0.31 \%$ & $0.00 \%$ & $0.00 \%$ & $0.00 \%$ & $0.00 \%$ \\
\hline $\begin{array}{l}\text { Private } \\
\text { Sector }\end{array}$ & $6.49 \%$ & $0.00 \%$ & $5.47 \%$ & $0.28 \%$ & $0.00 \%$ & $0.52 \%$ & $0.53 \%$ & $4.50 \%$ & $1.30 \%$ & $5.81 \%$ & $2.03 \%$ & $5.15 \%$ & $3.33 \%$ & $7.93 \%$ \\
\hline Market & $7.96 \%$ & $0.00 \%$ & $13.09 \%$ & $0.28 \%$ & $0.00 \%$ & $0.00 \%$ & $0.00 \%$ & $5.95 \%$ & $1.78 \%$ & $11.62 \%$ & $1.48 \%$ & $5.15 \%$ & $0.51 \%$ & $1.85 \%$ \\
\hline \multirow[t]{2}{*}{ Basic Needs } & $0.88 \%$ & $0.00 \%$ & $0.00 \%$ & $0.00 \%$ & $0.00 \%$ & $0.00 \%$ & $0.00 \%$ & $0.18 \%$ & $0.00 \%$ & $0.16 \%$ & $0.00 \%$ & $3.09 \%$ & $0.77 \%$ & $0.18 \%$ \\
\hline & $19.17 \%$ & $0.00 \%$ & $25.20 \%$ & $0.85 \%$ & $0.35 \%$ & $0.78 \%$ & $1.60 \%$ & $13.69 \%$ & $3.40 \%$ & $18.68 \%$ & $3.87 \%$ & $13.40 \%$ & $4.87 \%$ & $10.89 \%$ \\
\hline \multicolumn{15}{|l|}{$\begin{array}{l}\text { Post- } \\
\text { Washington } \\
\text { Consensus }\end{array}$} \\
\hline Poverty & $32.45 \%$ & $5.45 \%$ & $28.71 \%$ & $1.42 \%$ & $1.77 \%$ & $12.66 \%$ & $12.30 \%$ & $21.80 \%$ & $3.08 \%$ & $17.27 \%$ & $0.74 \%$ & $45.36 \%$ & $0.51 \%$ & $10.52 \%$ \\
\hline Institutions & $9.73 \%$ & $1.82 \%$ & $14.26 \%$ & $3.41 \%$ & $2.83 \%$ & $3.10 \%$ & $9.09 \%$ & $6.31 \%$ & $6.00 \%$ & $6.91 \%$ & $2.03 \%$ & $2.06 \%$ & $0.77 \%$ & $11.81 \%$ \\
\hline Governance & $2.06 \%$ & $1.82 \%$ & $0.59 \%$ & $2.56 \%$ & $1.06 \%$ & $3.36 \%$ & $7.49 \%$ & $17.12 \%$ & $4.05 \%$ & $6.12 \%$ & $1.48 \%$ & $1.03 \%$ & $1.28 \%$ & $7.01 \%$ \\
\hline Inequality & $7.37 \%$ & $0.00 \%$ & $6.25 \%$ & $0.28 \%$ & $0.00 \%$ & $3.10 \%$ & $0.53 \%$ & $2.88 \%$ & $1.62 \%$ & $3.14 \%$ & $0.18 \%$ & $0.00 \%$ & $0.26 \%$ & $17.53 \%$ \\
\hline Human rights & $7.08 \%$ & $5.45 \%$ & $4.30 \%$ & $7.10 \%$ & $0.00 \%$ & $1.55 \%$ & $0.53 \%$ & $3.78 \%$ & $0.65 \%$ & $2.35 \%$ & $0.55 \%$ & $0.00 \%$ & $3.08 \%$ & $1.29 \%$ \\
\hline \multirow[t]{2}{*}{ Civil Society } & $1.77 \%$ & $2.73 \%$ & $4.10 \%$ & $2.56 \%$ & $2.12 \%$ & $0.52 \%$ & $2.67 \%$ & $5.05 \%$ & $0.81 \%$ & $5.34 \%$ & $0.18 \%$ & $2.06 \%$ & $2.56 \%$ & $11.62 \%$ \\
\hline & $60.47 \%$ & $17.27 \%$ & $58.20 \%$ & $17.33 \%$ & $7.77 \%$ & $24.29 \%$ & $32.62 \%$ & $56.94 \%$ & $16.21 \%$ & $41.13 \%$ & $5.17 \%$ & $50.52 \%$ & $8.46 \%$ & $59.78 \%$ \\
\hline \multicolumn{15}{|l|}{$\begin{array}{l}\text { Security - } \\
\text { Development } \\
\text { Nexus }\end{array}$} \\
\hline Security & $4.42 \%$ & $62.73 \%$ & $3.71 \%$ & $20.17 \%$ & $19.79 \%$ & $38.76 \%$ & $2.14 \%$ & $8.11 \%$ & $38.74 \%$ & $12.56 \%$ & $60.15 \%$ & $11.34 \%$ & $16.92 \%$ & $2.95 \%$ \\
\hline Conflict & $9.73 \%$ & $16.36 \%$ & $9.77 \%$ & $52.84 \%$ & $69.26 \%$ & $25.32 \%$ & $2.67 \%$ & $14.95 \%$ & $12.64 \%$ & $16.17 \%$ & $9.23 \%$ & $17.53 \%$ & $40.51 \%$ & $10.52 \%$ \\
\hline Terrorism & $0.00 \%$ & $0.00 \%$ & $0.00 \%$ & $1.42 \%$ & $0.35 \%$ & $6.46 \%$ & $2.14 \%$ & $0.90 \%$ & $16.69 \%$ & $1.10 \%$ & $14.58 \%$ & $1.03 \%$ & $2.82 \%$ & $0.00 \%$ \\
\hline Failed States & $0.00 \%$ & $0.00 \%$ & $0.00 \%$ & $0.28 \%$ & $0.00 \%$ & $1.03 \%$ & $47.59 \%$ & $3.24 \%$ & $2.27 \%$ & $7.22 \%$ & $0.18 \%$ & $2.06 \%$ & $4.87 \%$ & $15.13 \%$ \\
\hline Stability & $6.19 \%$ & $2.73 \%$ & $2.93 \%$ & $6.25 \%$ & $2.47 \%$ & $2.33 \%$ & $11.23 \%$ & $1.62 \%$ & $7.13 \%$ & $2.51 \%$ & $6.09 \%$ & $3.09 \%$ & $21.03 \%$ & $0.55 \%$ \\
\hline Radicalism & $0.00 \%$ & $0.00 \%$ & $0.00 \%$ & $0.57 \%$ & $0.00 \%$ & $0.26 \%$ & $0.00 \%$ & $0.54 \%$ & $2.92 \%$ & $0.63 \%$ & $0.74 \%$ & $1.03 \%$ & $0.51 \%$ & $0.00 \%$ \\
\hline
\end{tabular}




\begin{tabular}{|c|c|c|c|c|c|c|c|c|c|c|c|c|c|c|}
\hline & $20.35 \%$ & $81.82 \%$ & $16.41 \%$ & $81.53 \%$ & $91.87 \%$ & $74.16 \%$ & $65.78 \%$ & $29.37 \%$ & $80.39 \%$ & $40.19 \%$ & $90.96 \%$ & $36.08 \%$ & $86.67 \%$ & $29.15 \%$ \\
\hline & $\begin{array}{l}1997 \\
\text { WP }\end{array}$ & $\begin{array}{l}1999 \\
\text { Security } \\
\text { Strategy }\end{array}$ & $\begin{array}{l}2000 \\
\text { WP }\end{array}$ & $\begin{array}{l}2003 \\
\text { GCPP }\end{array}$ & $\begin{array}{l}2004 \\
\text { ACCP }\end{array}$ & $\begin{array}{l}2005 \\
\text { Security } \\
\text { Paper }\end{array}$ & $\begin{array}{l}2005 \\
\text { Fragile } \\
\text { States }\end{array}$ & $\begin{array}{l}2006 \\
\text { WP }\end{array}$ & $\begin{array}{l}2008 \\
\text { NSS }\end{array}$ & $\begin{array}{l}2009 \\
\text { WP }\end{array}$ & $\begin{array}{l}2010 \\
\text { Security } \\
\text { Strategy }\end{array}$ & $\begin{array}{l}2011 \\
\text { UK aid }\end{array}$ & $\begin{array}{l}2011 \\
\text { Stability } \\
\text { Overseas }\end{array}$ & $\begin{array}{l}2011 \\
\text { Multilateral } \\
\text { Aid } \\
\text { Review }\end{array}$ \\
\hline $\begin{array}{l}\text { Washington } \\
\text { Consensus } \\
\text { Terms }\end{array}$ & $19.17 \%$ & $0.00 \%$ & $25.20 \%$ & $0.85 \%$ & $0.35 \%$ & $0.78 \%$ & $1.60 \%$ & $13.69 \%$ & $3.40 \%$ & $18.68 \%$ & $3.87 \%$ & $13.40 \%$ & $4.87 \%$ & $10.89 \%$ \\
\hline $\begin{array}{l}\text { Post- } \\
\text { Washington } \\
\text { Consensus } \\
\text { Terms }\end{array}$ & $60.47 \%$ & $17.27 \%$ & $58.20 \%$ & $17.33 \%$ & $7.77 \%$ & $24.29 \%$ & $32.62 \%$ & $56.94 \%$ & $16.21 \%$ & $41.13 \%$ & $5.17 \%$ & $50.52 \%$ & $8.46 \%$ & $59.78 \%$ \\
\hline $\begin{array}{l}\text { Security- } \\
\text { Development } \\
\text { Nexus } \\
\text { Terms }\end{array}$ & $20.35 \%$ & $81.82 \%$ & $16.41 \%$ & $81.53 \%$ & $91.87 \%$ & $74.16 \%$ & $65.78 \%$ & $29.37 \%$ & $80.39 \%$ & $40.19 \%$ & $90.96 \%$ & $36.08 \%$ & $86.67 \%$ & $29.15 \%$ \\
\hline
\end{tabular}


Table 6: Top 10 Recipients of DfID ODA 1997-2011*

\begin{tabular}{|c|c|c|c|c|c|c|c|c|c|c|c|c|c|c|c|}
\hline & 1997 & 1998 & 1999 & 2000 & 2001 & 2002 & 2003 & 2004 & 2005 & 2006 & 2007 & 2008 & 2009 & 2010 & 2011 \\
\hline 1 & $\begin{array}{l}\text { India } \\
153.96\end{array}$ & $\begin{array}{l}\text { India } \\
186.60\end{array}$ & $\begin{array}{l}\text { India } \\
131.68\end{array}$ & $\begin{array}{l}\text { Uganda } \\
216.57\end{array}$ & $\begin{array}{l}\text { Tanzani } \\
\text { a } \\
285.39\end{array}$ & $\begin{array}{l}\text { Serbia } \\
459.74\end{array}$ & $\begin{array}{l}\text { India } \\
329.88\end{array}$ & $\begin{array}{l}\text { India } \\
370.15\end{array}$ & $\begin{array}{l}\text { Nigeria } \\
2200.8 \\
9\end{array}$ & $\begin{array}{l}\text { Nigeria } \\
3185.7 \\
4\end{array}$ & $\begin{array}{l}\text { India } \\
510.53\end{array}$ & $\begin{array}{l}\text { Iraq } \\
639.04\end{array}$ & $\begin{array}{l}\text { India } \\
630.34\end{array}$ & $\begin{array}{l}\text { India } \\
650.34\end{array}$ & $\begin{array}{l}\text { Ethiopia } \\
552.25\end{array}$ \\
\hline 2 & $\begin{array}{l}\text { Guyana } \\
150.53\end{array}$ & $\begin{array}{l}\text { Tanzani } \\
\text { a } \\
158.63 \\
\end{array}$ & $\begin{array}{l}\text { Bangla } \\
\text { desh } \\
114.90 \\
\end{array}$ & $\begin{array}{l}\text { India } \\
204.16\end{array}$ & $\begin{array}{l}\text { Mozam } \\
\text { bique } \\
185.15 \\
\end{array}$ & $\begin{array}{l}\text { India } \\
343.72\end{array}$ & $\begin{array}{l}\text { Tanzani } \\
\text { a } \\
285.47 \\
\end{array}$ & $\begin{array}{l}\text { Congo, } \\
\text { Dem. Rep. } \\
300.97\end{array}$ & $\begin{array}{l}\text { Iraq } \\
1317.5 \\
2 \\
\end{array}$ & $\begin{array}{l}\text { India } \\
349.30\end{array}$ & $\begin{array}{l}\text { Ethiopi } \\
\text { a } \\
291.07\end{array}$ & $\begin{array}{l}\text { India } \\
613.12\end{array}$ & $\begin{array}{l}\text { Ethiopia } \\
342.92\end{array}$ & $\begin{array}{l}\text { Ethiopia } \\
406.95\end{array}$ & $\begin{array}{l}\text { India } \\
453.85\end{array}$ \\
\hline 3 & $\begin{array}{l}\text { Zambia } \\
93.71\end{array}$ & $\begin{array}{l}\text { Uganda } \\
105.56\end{array}$ & $\begin{array}{l}\text { Uganda } \\
96.38\end{array}$ & $\begin{array}{l}\text { Tanzania } \\
152.73\end{array}$ & $\begin{array}{l}\text { India } \\
173.88\end{array}$ & $\begin{array}{l}\text { Afghan } \\
\text { istan } \\
130.80\end{array}$ & $\begin{array}{l}\text { Bangla } \\
\text { desh } \\
260.47 \\
\end{array}$ & $\begin{array}{l}\text { Zambia } \\
282.55\end{array}$ & $\begin{array}{l}\text { India } \\
579.24\end{array}$ & $\begin{array}{l}\text { Afghan } \\
\text { istan } \\
246.49 \\
\end{array}$ & $\begin{array}{l}\text { Nigeria } \\
285.95\end{array}$ & $\begin{array}{l}\text { Afghanista } \\
\mathrm{n} \\
322.31 \\
\end{array}$ & $\begin{array}{l}\text { Afghanista } \\
\mathrm{n} \\
324.39 \\
\end{array}$ & $\begin{array}{l}\text { Pakistan } \\
298.51\end{array}$ & $\begin{array}{l}\text { Afghanista } \\
\mathrm{n} \\
423.42 \\
\end{array}$ \\
\hline 4 & $\begin{array}{l}\text { Uganda } \\
78.18\end{array}$ & $\begin{array}{l}\text { Bangla } \\
\text { desh } \\
98.95\end{array}$ & $\begin{array}{l}\text { Ghana } \\
91.78\end{array}$ & $\begin{array}{l}\text { Zambia } \\
111.41\end{array}$ & $\begin{array}{l}\text { Banglad } \\
\text { esh } \\
124.47\end{array}$ & $\begin{array}{l}\text { Ghana } \\
122.49\end{array}$ & $\begin{array}{l}\text { Iraq } \\
179.98\end{array}$ & $\begin{array}{l}\text { Ghana } \\
280.03\end{array}$ & $\begin{array}{l}\text { Tanzan } \\
\text { ia } \\
220.35\end{array}$ & $\begin{array}{l}\text { Tanzan } \\
\text { ia } \\
218.86\end{array}$ & $\begin{array}{l}\text { Afghan } \\
\text { istan } \\
268.71\end{array}$ & $\begin{array}{l}\text { Pakistan } \\
260.32\end{array}$ & $\begin{array}{l}\text { Sudan } \\
292.42\end{array}$ & $\begin{array}{l}\text { Nigeria } \\
264.61\end{array}$ & $\begin{array}{l}\text { Congo, } \\
\text { Dem. Rep. } \\
383.05\end{array}$ \\
\hline 5 & $\begin{array}{l}\text { Mozambique } \\
72.48\end{array}$ & $\begin{array}{l}\text { Montse } \\
\text { rrat } \\
65.10 \\
\end{array}$ & $\begin{array}{l}\text { Tanzani } \\
\text { a } \\
88.63 \\
\end{array}$ & $\begin{array}{l}\text { Bangladesh } \\
103.36\end{array}$ & $\begin{array}{l}\text { Ghana } \\
97.84\end{array}$ & $\begin{array}{l}\text { Tanzan } \\
\text { ia } \\
109.31\end{array}$ & $\begin{array}{l}\text { Ghana } \\
123.90\end{array}$ & $\begin{array}{l}\text { Iraq } \\
275.10\end{array}$ & $\begin{array}{l}\text { Afghan } \\
\text { istan } \\
219.92 \\
\end{array}$ & $\begin{array}{l}\text { Sudan } \\
215.55\end{array}$ & $\begin{array}{l}\text { Bangla } \\
\text { desh } \\
245.57 \\
\end{array}$ & $\begin{array}{l}\text { Tanzania } \\
254.22\end{array}$ & $\begin{array}{l}\text { Bangladesh } \\
250.08\end{array}$ & $\begin{array}{l}\text { Congo, } \\
\text { Dem. Rep. } \\
250.78\end{array}$ & $\begin{array}{l}\text { Bangladesh } \\
368.62\end{array}$ \\
\hline 6 & $\begin{array}{l}\text { Bangladesh } \\
70.29\end{array}$ & $\begin{array}{l}\text { Ghana } \\
64.63\end{array}$ & $\begin{array}{l}\text { Malawi } \\
77.27\end{array}$ & $\begin{array}{l}\text { Malawi } \\
96.89\end{array}$ & $\begin{array}{l}\text { Uganda } \\
82.22\end{array}$ & $\begin{array}{l}\text { Bangla } \\
\text { desh } \\
101.82\end{array}$ & $\begin{array}{l}\text { South } \\
\text { Africa } \\
122.91\end{array}$ & $\begin{array}{l}\text { Bangladesh } \\
252.72\end{array}$ & $\begin{array}{l}\text { Bangla } \\
\text { desh } \\
203.27\end{array}$ & $\begin{array}{l}\text { Uganda } \\
214.41\end{array}$ & $\begin{array}{l}\text { Tanzan } \\
\text { ia } \\
230.69\end{array}$ & $\begin{array}{l}\text { Ethiopia } \\
253.68\end{array}$ & $\begin{array}{l}\text { Congo, } \\
\text { Dem. Rep. } \\
225.46\end{array}$ & $\begin{array}{l}\text { Tanzania } \\
240.94\end{array}$ & $\begin{array}{l}\text { Pakistan } \\
331.59\end{array}$ \\
\hline 7 & $\begin{array}{l}\text { Tanzania } \\
67.63\end{array}$ & $\begin{array}{l}\text { Malawi } \\
56.65\end{array}$ & $\begin{array}{l}\text { Zambia } \\
63.58\end{array}$ & $\begin{array}{l}\text { Sts Ex-Yugo. } \\
\text { Unspec. } \\
95.22 \\
\end{array}$ & $\begin{array}{l}\text { Malawi } \\
63.94\end{array}$ & $\begin{array}{l}\text { Peru } \\
84.43\end{array}$ & $\begin{array}{l}\text { Pakista } \\
\mathrm{n} \\
112.12\end{array}$ & $\begin{array}{l}\text { Afghanista } \\
\mathrm{n} \\
224.01 \\
\end{array}$ & $\begin{array}{l}\text { Sudan } \\
196.46\end{array}$ & $\begin{array}{l}\text { Pakista } \\
\mathrm{n} \\
203.17 \\
\end{array}$ & $\begin{array}{l}\text { Sudan } \\
206.17\end{array}$ & $\begin{array}{l}\text { Bangladesh } \\
252.53\end{array}$ & $\begin{array}{l}\text { Pakistan } \\
217.51\end{array}$ & $\begin{array}{l}\text { Afghanista } \\
\mathrm{n} \\
234.83 \\
\end{array}$ & $\begin{array}{l}\text { Nigeria } \\
298.86\end{array}$ \\
\hline 8 & $\begin{array}{l}\text { Indonesia } \\
57.22\end{array}$ & $\begin{array}{l}\text { China } \\
55.43\end{array}$ & $\begin{array}{l}\text { South } \\
\text { Africa } \\
62.92 \\
\end{array}$ & $\begin{array}{l}\text { China } \\
83.44\end{array}$ & $\begin{array}{l}\text { Zambia } \\
55.76\end{array}$ & $\begin{array}{l}\text { Uganda } \\
83.98\end{array}$ & $\begin{array}{l}\text { Malawi } \\
106.35\end{array}$ & $\begin{array}{l}\text { Tanzania } \\
215.63\end{array}$ & $\begin{array}{l}\text { Zambia } \\
165.73\end{array}$ & $\begin{array}{l}\text { Iraq } \\
203.00\end{array}$ & $\begin{array}{l}\text { Pakista } \\
\mathrm{n} \\
197.84\end{array}$ & $\begin{array}{l}\text { Sudan } \\
199.16\end{array}$ & $\begin{array}{l}\text { Tanzania } \\
216.65\end{array}$ & $\begin{array}{l}\text { Bangladesh } \\
228.32\end{array}$ & $\begin{array}{l}\text { Mozambiq } \\
\text { ue } \\
186.40\end{array}$ \\
\hline 9 & $\begin{array}{l}\text { Sts Ex- } \\
\text { Yugo. } \\
\text { Unspec. } \\
50.34\end{array}$ & $\begin{array}{l}\text { South } \\
\text { Africa } \\
54.12\end{array}$ & $\begin{array}{l}\text { China } \\
59.25\end{array}$ & $\begin{array}{l}\text { Mozambique } \\
82.66\end{array}$ & $\begin{array}{l}\text { Kenya } \\
55.12\end{array}$ & $\begin{array}{l}\text { Pakista } \\
\mathrm{n} \\
66.90\end{array}$ & $\begin{array}{l}\text { Uganda } \\
104.65\end{array}$ & $\begin{array}{l}\text { Ethiopia } \\
147.13\end{array}$ & $\begin{array}{l}\text { Ghana } \\
119.74\end{array}$ & $\begin{array}{l}\text { Serbia } \\
180.49\end{array}$ & $\begin{array}{l}\text { Uganda } \\
166.13\end{array}$ & $\begin{array}{l}\text { Mozambiq } \\
\text { ue } \\
197.88\end{array}$ & $\begin{array}{l}\text { Nigeria } \\
188.89\end{array}$ & $\begin{array}{l}\text { Uganda } \\
179.26\end{array}$ & $\begin{array}{l}\text { Tanzania } \\
158.92\end{array}$ \\
\hline 10 & $\begin{array}{l}\text { Kenya } \\
46.6\end{array}$ & $\begin{array}{l}\text { Kenya } \\
54.08\end{array}$ & $\begin{array}{l}\text { Kenya } \\
55.02\end{array}$ & $\begin{array}{l}\text { Ghana } \\
79.91\end{array}$ & $\begin{array}{l}\text { Sierra } \\
\text { Leone } \\
51.13\end{array}$ & $\begin{array}{l}\text { Kenya } \\
54.39\end{array}$ & $\begin{array}{l}\text { Afghani } \\
\text { stan } \\
98.61\end{array}$ & $\begin{array}{l}\text { Nigeria } \\
126.09\end{array}$ & $\begin{array}{l}\text { Malawi } \\
101.96\end{array}$ & $\begin{array}{l}\text { Malawi } \\
170.94\end{array}$ & $\begin{array}{l}\text { China } \\
162.43\end{array}$ & $\begin{array}{l}\text { Congo, } \\
\text { Dem. Rep. } \\
192.85\end{array}$ & $\begin{array}{l}\text { Ghana } \\
153.93\end{array}$ & $\begin{array}{l}\text { Ghana } \\
166.58\end{array}$ & $\begin{array}{l}\text { Sudan } \\
157.34\end{array}$ \\
\hline
\end{tabular}

*Source the Organisation for Economic Cooperation on Development-Development Assistance 